\title{
Mother-requested cesarean delivery compared to vaginal delivery: a systematic review
}

\section{Parto Cesáreo a pedido materno comparado COM PARTO VAGINAL: ReVISÃo sistemática}

luca S. Bernardo, Ricardo Simões, Wanderley M. Bernardo, Sergio F. de Toledo, Mario A. Hazzan, Henry F. Chan,

Kira B. Bucci, Gustavo Mercuri

\section{INTRODUCTION}

The rates of c-sections without medical or obstetric indication have increased substantially in the last decades, especially in developing countries. Many factors contribute to this increase, being the mother-requested cesarean delivery a key contributing factor. There is a major debate about the implementation of c-sections performed at the mother's request without any established medical indication, and safety, cost, maternal autonomy, maternal and professional satisfaction, and ethics constitute important factors under discussion.

\section{Objective}

To prepare a recommendation considering the risks and benefits involved in the practice of mother-requested cesarean delivery and c-section without medical indication, compared to the planned vaginal delivery.

\section{Material AND Methods}

The evidence used for analysis of the risks and benefits involved in the practice of mother-requested cesarean delivery and c-section without medical indication was obtained according to the following steps: preparation of the clinical question, structuring of the question, search for evidence, critical evaluation and selection of evidence. The measures of effectiveness or damage expressed in absolute numbers were analyzed using difference in absolute risk, adopting a confidence interval of $95 \%$. For statistically significant results, the number needed to treat to benefit (NNT) and the number needed to treat to harm $(\mathrm{NNH})$ were calculated. The meta-analysis was performed using RevMan 5 interface.

\section{RESULTS}

Using the search strategy described, 1,482 studies were retrieved. Out of these, which were reviewed based on title, only 295 articles included the subject mother-requested cesarean delivery or c-section without medical indication, and thus 1,187 studies were excluded. Of the 295 remaining studies, only 73 were selected for full text review, so that nine comparative studies (observational cohorts) that met the criteria for inclusion and exclusion were considered for final evaluation. The results with significant difference were: mother-requested cesarean delivery or c-section without medical indication increases the risk of hemorrhagic (Figure 1), infectious (Figure 2) and breastfeeding complications (Figure 3), and respiratory complications in the newborn (Figure 4). They also point toward a reduction in the risk of emergency c-sections (Figure 5) and Apgar score $\leq 7$ (Figure 6) compared to planned vaginal deliveries. The requested cesarean delivery does not establish significant differences in maternal mortality, post surgical wound complications, neonatal asphyxia, neonatal infection, and admission to neonatal ICU.

\section{Conclusion}

Despite the heterogeneity seen in the results of the meta-analysis, we were able to conclude that the performance of mother-requested cesarean section, or c-section without indication, increases the risk of hemorrhagic, infectious and breastfeeding complications, as well as respiratory complications in the newborn, also reducing the risk of Apgar score $\leq 7$, compared to the vaginal delivery. 


\begin{tabular}{|c|c|c|c|c|c|c|c|c|}
\hline \multirow[b]{2}{*}{ Study or subgroup } & \multirow[b]{2}{*}{ Events } & \multirow{2}{*}{$\begin{array}{l}\text { CDMR } \\
\text { Total }\end{array}$} & \multirow[b]{2}{*}{ Events } & \multicolumn{2}{|c|}{ Vaginal delivery } & \multicolumn{2}{|l|}{ Risk difference } & \multirow{2}{*}{$\begin{array}{l}\text { Risk difference } \\
\text { M-H, fixed, } 95 \% \mathrm{Cl}\end{array}$} \\
\hline & & & & Total & Weight & $\mathrm{M}-\mathrm{H}$, fixed, 95\% Cl & Year & \\
\hline Karlström 2013 & 0 & 5,877 & 838 & 13,774 & $68.9 \%$ & $-0.06[-0.06,-0.06]$ & 2013 & $=$ \\
\hline Crowther 2012 & 109 & 1,098 & 367 & 1,225 & $9.7 \%$ & $-0.20[-0.23,-0.17]$ & 2012 & \\
\hline Larsson 2011 & 25 & 247 & 45 & 294 & $2.2 \%$ & $-0.05[-0.11,0.00]$ & 2011 & \\
\hline Dahigren 2009 & 0 & 1,046 & 5,580 & 38,021 & $17 \%$ & $-0.15[-0.15,-0.14]$ & 2009 & \\
\hline Schindl 2003 & 0 & 147 & 93 & 903 & $2.1 \%$ & $-0.10[-0.12,-0.08]$ & 2003 & $\boldsymbol{\varphi}$ \\
\hline Total $(95 \% \mathrm{Cl})$ & & 8,415 & & 54,217 & $100 \%$ & $-0.09[-0.09,-0.09]$ & & \\
\hline Total events & 134 & & 6,923 & & & & & 0.0250 .05 \\
\hline
\end{tabular}

FIGURE 5 Emergency c-section score.

\begin{tabular}{|c|c|c|c|c|c|c|c|c|}
\hline \multirow[b]{2}{*}{ Study or subgroup } & \multirow[b]{2}{*}{ Events } & \multirow{2}{*}{$\begin{array}{l}\text { CDMR } \\
\text { Total }\end{array}$} & \multirow[b]{2}{*}{ Events } & \multicolumn{2}{|c|}{ Vaginal delivery } & \multicolumn{2}{|l|}{ Risk difference } & \multirow{2}{*}{$\begin{array}{l}\text { Risk difference } \\
\text { M-H, fixed, } 95 \% \mathrm{Cl}\end{array}$} \\
\hline & & & & Total & Weight & $\mathrm{M}-\mathrm{H}$, fixed, $95 \% \mathrm{Cl}$ & Year & \\
\hline Karlström 2013 & 0 & 1,046 & 182 & 38,021 & $17.8 \%$ & $-0.00[-0.01,-0.00]$ & 2013 & $=$ \\
\hline Crowther 2012 & 38 & 5,877 & 252 & 13,774 & $72.1 \%$ & $-0.01[-0.01,-0.01]$ & 2012 & \\
\hline Dahigren 2009 & 0 & 1,098 & 1 & 1,225 & $10.1 \%$ & $-0.00[-0.00,0.00]$ & 2009 & \\
\hline Total $(95 \% \mathrm{Cl})$ & & 8,021 & & 53,020 & $100 \%$ & $-0.01[-0.01,-0.01]$ & & $\bullet$ \\
\hline Total events & 38 & & 435 & & & & & \\
\hline \multicolumn{8}{|c|}{$\begin{array}{l}\text { Heterogeneity: } \mathrm{Chi}^{2}=92.86, \mathrm{df}=2(\mathrm{p}<0.00001) ; \mathrm{I}^{2}=98 \% \\
\text { Test for overall effect: } \mathrm{Z}=8.37(\mathrm{p}<0.00001)\end{array}$} & $\begin{array}{ccc}-0.05 & 0.025 & 0.05 \\
\text { Favours [CS] } & \text { Favours [VD] }\end{array}$ \\
\hline
\end{tabular}

FIGURE 6 Apgar score. 